\title{
Microwave Drying of Banana (Musa acuminata) Stalk Biomass before Conversion to Value- added Products
}

\author{
${ }^{1}$ Agbede, O. O., ${ }^{1}$ Odewale, I. S., ${ }^{2}$ Oke, E. O. and ${ }^{1 *}$ Aworanti, O. A. \\ ${ }^{1}$ Department of Chemical Engineering, Ladoke Akintola University of Technology, Ogbomoso, Oyo State, Nigeria. \\ ${ }^{2}$ Department of Chemical Engineering, Michael Okpara University of Agriculture, Umudike, Abia State, Nigeria.
}

Corresponding E-mail: oaaworanti@lautech.edu.ng

Submitted on: 21/09/2020;

Accepted on: 10/02/2021

\begin{abstract}
Banana stalk biomass can pose disposal, environmental and health challenges. Fortunately, this biomass can be converted to value-added products including biofuels, bioenergy, biosorbents, fibers and animal feeds. However, it is necessary to remove moisture from the fresh biomass by drying before storage and conversion processes. Conventional drying in open sun is slow and weather dependent, but higher heating rates and faster drying rates can be achieved in a microwave dryer. Hence, the microwave drying characteristic of banana stalk biomass was investigated. Banana stalks were sliced into $5 \mathrm{~mm}$ thick pieces and dried in a microwave oven at power levels of $400-$ $1000 \mathrm{~W}$, the stalk slices were weighed at interval until the mass remained constant. The effective moisture diffusivity, activation energy and energy required for drying were determined. The microwave drying data were also fitted to twelve thin layer drying mathematical models to describe the kinetics of the drying process. The drying time of banana stalk slices decreased with increasing microwave power. The drying occurred mainly in the falling rate period. The effective moisture diffusivities were $4.14 \times 10^{-9}-2.00 \times 10^{-8} \mathrm{~m}^{2} \mathrm{~s}^{-1}$ at $400-1000 \mathrm{~W}$. The activation energy was 122 $\mathrm{W}^{-1}$ while the total and specific energies required for the microwave drying were $0.25-0.37 \mathrm{kWh}$ and $34.8-51 \mathrm{kWh} / \mathrm{kg}$, respectively. The Weibull model suitably described the microwave drying kinetics of banana stalk slices. The moisture present in fresh banana stalk waste biomass can be effectively and rapidly removed by microwave drying before conversion processes.
\end{abstract}

Keywords: Banana stalk biomass; microwave drying; drying energy; drying kinetics.

\section{Introduction}

Banana is a nutritious fruit crop that is consumed as snack or processed into other consumer products globally (Mohapatra et al., 2011; FAO, 2020a). It belongs to the family Musaceae (Simmonds, 1962; Mohapatra et al., 2010). Banana is grown in many countries of the world for domestic consumption and as an export produce (FAO, 2020a; FAO, 2020b). A huge amount of residues which include rhizomes, pseudo-stems, stalks, peels and leaves, are generated through the production, processing and consumption of banana (Padam et al., 2014; Fernandes et al., 2013; Guerrero et al., 2016). This large quantity of residues can pose disposal and environmental pollution problems (Guerrero et al., 2016).

However, banana stalk biomass can be converted into useful material, biofuels and bioenergy. They can be utilized as adsorbents for the removal of pollutants from wastewater (Shibi et al., 2006; Hameed et al., 2008; Ogunleye et al., 2014; Ogunleye et al., 2015a; Ogunleye et al., 2015b). Fibers from banana stalk can be used as reinforcement in composite materials as well as in the production of textile and paper (Zuluaga et al., 2007; Zuluaga et al., 2009; Leao et al., 2010; Mohapatra et al., 2010; Deumaga et al., 2015; Ogunsile and Oladeji, 2016). Banana stalk can also be processed into feeds for animal consumption (Poyyamozhi and Kadirvel, 1986; Viswanathan et al., 1989; Ajila et $a l ., 2012$ ). In addition, banana stalk biomass can be converted to biofuels and bioenergy through gasification, pyrolysis, hydrothermal carbonization, torrefaction, direct combustion and 
fermentation processes (Santa-Maria et al., 2013; Granados et al., 2014; Guerrero et al., 2016; Dhyani and Bhaskar, 2017; Gumisiriza, et al., 2017; Guerreroa et al., 2018; Liao et al., 2018; Barskov et al., 2019; Islam et al., 2019).

Drying is a preservation method employed basically to lessen the moisture content of agricultural produce; it reduces enzyme and microbial activities in the material thus enhancing the shelf-life of the products, it also decreases packaging and transportation cost (Mujumdar and Law, 2010).

The removal of moisture from banana stalk before its storage is necessary for the preservation of fresh banana stalk biomass after harvesting and removal of the banana fruit. It is also essential to remove moisture from banana stalk during the production of adsorbents and animal feeds from the biomass (Viswanathan et al., 1989; Ogunleye et al., 2014; Ogunleye et al., 2015a; Ogunleye et al., 2015b). Besides, the high moisture in banana stalk biomass would limit the efficiencies of direct combustion, torrefaction, gasification and pyrolysis, so drying is essential to reduce the moisture content prior to these processes (Hughes and Larson, 1998; McKendry, 2002; Demirbas, 2004; Granados et al., 2014).

Open sun drying is the traditional technique for drying agricultural produce; it uses free solar energy, so it is cheap. However, it is weather dependent, requires long drying time and the material is adversely exposed to rodents, insects, dust and rainfall. However, microwave drying uses electromagnetic microwaves to internally heat the material causing a quick evaporation of water as a result of the rapid absorption of microwave energy by water molecules (Chandrasekaran et al., 2013; Rattanadecho and Makul, 2015; Wray and Ramaswamy, 2015). Faster drying rates and shorter drying times are achieved in microwave dryer compared to open sun (Agbede et al., 2020). The microwave drying of banana stalk biomass has not been previously reported.

Mass and heat transfer properties of banana stalk biomass including effective moisture diffusivity, activation energy and energy required for drying are essential for the design and operation of efficient dryers because drying is a coupled mass and heat transfer process. Thin layer drying mathematical models are useful for the design, operation, optimization and control of drying processes; they have been used to describe the drying behavior of agricultural products (Erbay and Icier, 2010; Kucuk et al., 2014). They can be used to estimate drying times (Akpinar and Bicer, 2008).

Hence, this study aimed at determine the microwave drying characteristics of banana stalk, including the drying rates, effective moisture diffusivities, activation energy, drying energy requirement as well as the thin layer drying mathematical model that best describe the drying process.

\section{Materials and Methods}

\section{Sample Collection and Preparation}

Banana stalks were obtained from freshly harvested banana bunches sold in a local market in Ogbomoso, Nigeria. The stalks were cleaned and then cut into slices of $5 \mathrm{~mm}$ thickness using a knife. The equivalent diameter of the banana stalk was about $33 \mathrm{~mm}$. A banana stalk is shown in Figure 1. 


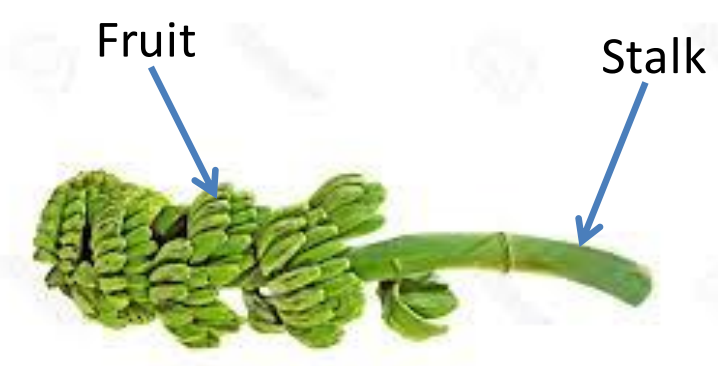

Figure 1: A bunch of bananas

\section{Microwave Drying Procedure}

A banana stalk slice was weighed and then placed on the rotating disc of a Hisense H36MOMMMI microwave oven. The microwave power level was set to $400 \mathrm{~W}$ and the material was heated for 5 min after which the sample was removed from the microwave oven and weighed. The microwave heating and subsequent weighing of the material continued until its mass remained constant. The microwave drying experiments were repeated using power levels of 600, 800 and $1000 \mathrm{~W}$ and heating times of 5, 3 and 3 min, respectively. The experiments were carried out in triplicates at each power level.

\section{Analysis of Microwave Drying Data}

The moisture content of the banana stalk slice at time, $t, X_{t}\left(\mathrm{~g}\right.$ water. $\mathrm{g}$ dry matter $\left.{ }^{-1}\right)$ was defined as:

$$
X_{t}=\frac{m_{t}-m_{d}}{m_{d}}
$$

where $m_{t}$ and $m_{d}$ are mass $(\mathrm{g})$ of the banana stalk slice at any time (min) $t$ and mass $(\mathrm{g})$ of absolutely dried slice, respectively. The moisture content was further transformed to a dimensionless moisture ratio $\left(M_{R}\right)$ defined as:

$$
M_{R}=\frac{X_{t}-X_{e}}{X_{i}-X_{e}}
$$

where $X_{i}$ and $X_{e}$ are initial and equilibrium moisture contents, respectively. For a long drying time, the values of $X_{e}$ are small compared with $X_{t}$ and $X_{i}$, so the moisture ratio can be simplified to equation 3 (Perea-Flores et al., 2012):

$$
M_{R}=\frac{X_{t}}{X_{i}}
$$

The drying rate of the banana stalk slice was expressed as:

$$
D_{R}=\frac{X_{t+d t}-X_{t}}{d t}
$$

where $D_{R}$ is drying rate (g water/g dry matter. $\min$ ), $X_{t+d t}$ is moisture content at time $t+d t(\mathrm{~g}$ water. $g$ dry matter ${ }^{-1}$ ) and $d t$ is time increment (min). 
The internal mass transfer is the rate controlling mechanism during the falling rate period, so the Fick's second law of diffusion can be used to describe the diffusion of moisture from the internal part of the stalk slice to its surface (Doymaz, 2008; Agbede et al., 2020). The Fick's law in terms of the moisture ratio was expressed as (Vega-Galvez et al, 2010):

$$
\frac{d M_{R}}{d t}=D_{e f f} \frac{d^{2} M_{R}}{d x^{2}}
$$

where $D_{\text {eff }}$ is the effective moisture diffusivity $\left(\mathrm{m}^{2} \mathrm{~s}^{-1}\right)$ and $x$ is spatial dimension $(\mathrm{m})$. The solution of this equation proposed by Crank (1975) is:

$$
M_{R}=\frac{8}{\pi^{2}} \sum_{i=0}^{\infty} \frac{1}{(2 i+1)^{2}} \exp \left[\frac{-(2 i+1)^{2} D_{\text {eff }} \pi^{2} t}{4 L^{2}}\right]
$$

This is based on the assumption of a one-dimensional transport of moisture in an infinite banana stalk slab, negligible shrinkage, uniform initial moisture distribution, constant diffusivity and negligible external resistant. A good estimate of the solution is given by the first term in the series expansion of equation (6), for sufficiently long drying time (Di Scala and Crapiste, 2008):

$$
M_{R}=\frac{8}{\pi^{2}} \exp \left[\frac{-D_{\text {eff }} \pi^{2} t}{4 L^{2}}\right]
$$

where $L$ is half of the thickness of the slab (m) and $t$ the drying time (min). A linear form of equation (7) is:

$$
\operatorname{In}\left(M_{R}\right)=\operatorname{In}\left(\frac{8}{\pi^{2}}\right)-\left(\frac{D_{e f f} \pi^{2} t}{4 L^{2}}\right)
$$

A plot of $\operatorname{In}\left(M_{R}\right)$ versus $t$ results in a straight line with slope $\left(S_{D}\right)$ from which $D_{e f f}$ was calculated:

$$
S_{D}=\frac{D_{e f f} \pi^{2}}{4 L^{2}}
$$

The microwave power dependence of the effective moisture diffusivity can be described by an Arrhenius-type relationship (Olanipekun et al., 2015):

$$
D_{\text {eff }}=D_{o} \exp \left[\frac{-E_{a} m}{P}\right]
$$

where $D_{o}$ is the Arrhenius or pre-exponential factor $\left(\mathrm{m}^{2} \mathrm{~s}^{-1}\right), E_{a}$ the activation energy $\left(\mathrm{W} \mathrm{g} \mathrm{g}^{-1}\right), P$ the microwave power (W) level and $m$ the mass (g) of fresh banana stalk slice. A linear form of equation (10) is:

$$
\text { In } D_{\text {eff }}=\operatorname{In} D_{o}-\frac{E_{a} m}{P}
$$

The activation energy $E_{a}$ can be determined from the slope $\left(S_{E}\right)$ of the straight line obtained from the plot of $\operatorname{In} D_{\text {eff }}$ versus $\mathrm{m} / \mathrm{P}$ :

$$
S_{E}=E_{a}
$$


LAUTECH Journal of Civil and Environmental Studies

Volume 6, Issue 1; March 2021

The total energy $E_{t}(\mathrm{kWh})$ and specific energy $E_{s p}(\mathrm{kWh} / \mathrm{kg}$ banana stalk) required for microwave drying of fresh banana stalk were computed from equations 13 and 14, respectively:

$$
\begin{aligned}
E_{t} & =P \times D_{t} \\
E_{s p} & =\frac{E_{t}}{m_{i}-m_{d}}
\end{aligned}
$$

where $P$ is microwave power $(\mathrm{kW})$ and $D_{t}$ is the total drying time $(\mathrm{h}), m_{i}$ is initial mass of the banana stalk slice $(\mathrm{kg})$ and $m_{d}$ is mass of the absolutely dried banana stalk slice $(\mathrm{kg})$.

\section{Thin Layer Mathematical Modelling of Microwave Drying Kinetics}

The twelve thin layer models presented in Table 1 are those that have most frequently well described the drying kinetics of agricultural products (Kucuk et al., 2014), so they were fitted to the drying data to identify the model that most suitably describe the microwave drying kinetics of banana stalk. The data were fitted to the models by nonlinear regression analysis using the Statistical Package for the Social Sciences (SPSS) version 20 software. The statistical parameters used as criteria to determine the model that best describe the microwave drying data were the coefficient of determination $\left(R^{2}\right)$, sum of square error $(S S E)$, root mean square error (RMSE) and Chi-square $\left(\chi^{2}\right.$ ). The model that best describes the experimental data is one that has the highest value of $R^{2}$ and lowest values of SSE, RMSE and $\chi^{2}$ (Kucuk et al., 2014). The values of SSE, RMSE and $\chi^{2}$ were calculated from equations 15, 16 and 17, respectively, using Microsoft Excel, but $R^{2}$ values were obtained from the SPSS software.

\begin{tabular}{|c|c|c|c|}
\hline No & Model Name & Model Equation & References \\
\hline 1 & Midilli-Kucuk & $M_{R}=a \exp \left(-k t^{n}\right)+b t$ & $\begin{array}{l}\text { Midilli et al. } \\
\text { (2002) }\end{array}$ \\
\hline 2 & Page & $M_{R}=\exp \left(-k t^{n}\right)$ & Page (1949) \\
\hline 3 & Logarithmic & $M_{R}=a \exp (-k t)+c$ & $\begin{array}{l}\text { Chandra and Singh } \\
\text { (1995) }\end{array}$ \\
\hline 4 & Two-term & $M_{R}=a \exp \left(-k_{0} t\right)+b \exp \left(-k_{1} t\right)$ & $\begin{array}{l}\text { Henderson (1974), } \\
\text { Glenn (1978) }\end{array}$ \\
\hline 5 & Wang and Singh & $M_{R}=1+a t+b t^{2}$ & $\begin{array}{l}\text { Wang and Singh } \\
(1978)\end{array}$ \\
\hline 6 & Approximation of diffusion & $M_{R}=a \exp (-k t)+(1-a) \exp (-k b t)$ & Kaseem (1998) \\
\hline 7 & $\begin{array}{l}\text { Modified Henderson and } \\
\text { Pabis }\end{array}$ & $M_{R}=a \exp (-k t)+b \exp (-g t)+c \exp (-h t)$ & Karathanos (1999) \\
\hline 8 & Modified Page & $M_{R}=\exp \left(-(k t)^{n}\right)$ & White et al. (1978) \\
\hline 9 & Henderson and Pabis & $M_{R}=a \exp (-k t)$ & $\begin{array}{l}\text { Henderson and } \\
\text { Pabis (1961) }\end{array}$ \\
\hline 10 & Two-term exponential & $M_{R}=a \exp (-k t)+(1-a) \exp (-k a t)$ & $\begin{array}{l}\text { Sharaf-Eldeen } e t \\
\text { al. (1980) }\end{array}$ \\
\hline 11 & Verma & $M_{R}=a \exp (-k t)+(1-a) \exp (-g t)$ & $\begin{array}{l}\text { Verma et al. } \\
(1985)\end{array}$ \\
\hline 12 & Weibull & $M_{R}=a-b \exp \left(-k t^{n}\right)$ & Weibull (1951) \\
\hline
\end{tabular}

Table 1: Thin layer drying models fitted to drying data 


$$
\begin{aligned}
S S E & =\frac{1}{N} \sum_{i=1}^{N}\left(M_{R_{\text {exp }, i}}-M_{R_{\text {pred }, i}}\right)^{2} \\
R M S E & =\left[\frac{1}{N} \sum_{i=1}^{N}\left(M_{R_{\text {pred }, i}}-M_{R_{\text {exp }, i}}\right)^{2}\right]^{\frac{1}{2}} \\
\chi^{2} & =\frac{\sum_{i=1}^{N}\left(M_{R_{\text {exp }, i}-}-M_{R_{\text {pred }, i}}\right)^{2}}{N-z}
\end{aligned}
$$

where $M_{R_{\text {exp, },}}, M_{R_{\text {pred }, i}}, N$ and $z$ are experimental moisture ratio, predicted moisture ratio, number of observations and number of constants, respectively.

\section{Results and Discussion}

\section{Drying Curves}

The plots of moisture ratio versus drying time for the microwave drying of banana stalk slices at $400-1000 \mathrm{~W}$ are shown in Figure 2. The moisture ratio decreased as the microwave drying progressed, indicating that moisture was effectively removed from the banana stalk slices by microwave heating. The drying times decreased with increasing microwave power level; drying times of 55, 35, 27 and 15 min, were observed at 400, 600, 800 and $1000 \mathrm{~W}$, respectively. Higher drying rates and shorter drying times were achieved at higher microwave power levels because the larger thermal energy generated by higher microwave energy available at elevated microwave power levels resulted in a more rapid evaporation of moisture from the banana stalk slices (Chandrasekaran, et al., 2013). Shorter drying times at higher microwave power levels have been reported for the microwave drying of spinach (Alibas Ozkan et al., 2007), mint leaves (Özbek and Dadali, 2007), basil (Demirhan and Özbek, 2009), coriander (Sarimeseli, 2011), turmeric slices (Surendhar et al., 2019) and green microalgae paste biomass (Agbede et al., 2020).

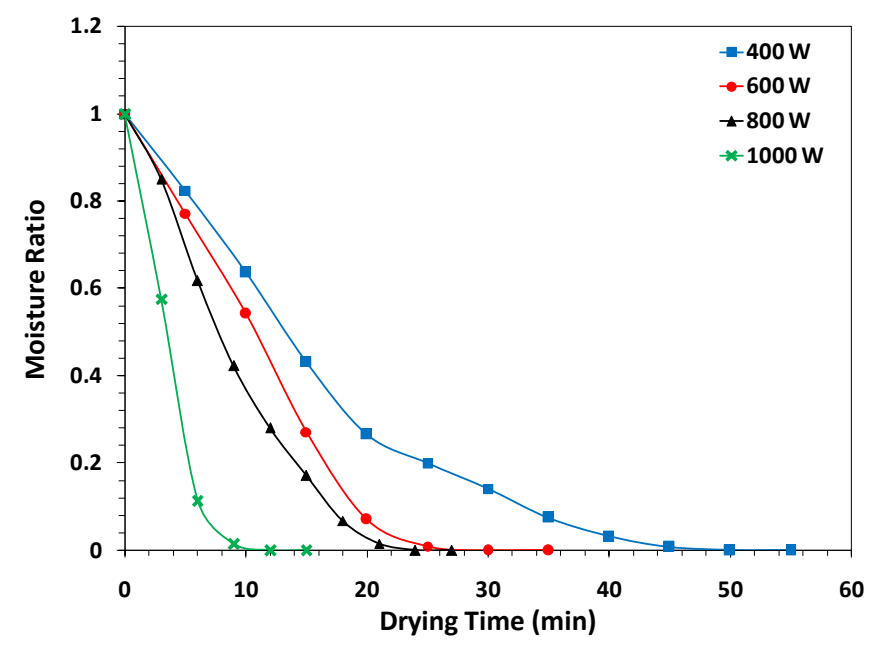

Figure 2: Plot of moisture ratio versus drying time for microwave drying of banana stalk slices

\section{Drying Rates}

The plots of drying rates versus drying times for the microwave drying of banana stalk slices at 400 $-1000 \mathrm{~W}$ are shown in Figure 3. At each of the power levels studied, the drying rate initially increased briefly during the warming up stage then decreased with drying time. The highest drying rates were $0.52,0.62,0.99$ and $1.79 \mathrm{~g}$ water / g dry matter.min at 400, 600, 800 and $1000 \mathrm{~W}$, 
LAUTECH Journal of Civil and Environmental Studies

Volume 6, Issue 1; March 2021

respectively. Higher initial drying rates were observed at higher microwave powers. The drying took place mainly in the falling rate period and was controlled by diffusion of moisture from the inner part of the banana stalk slice to its surface (Doymaz, 2008; Ruiz Celma et al., 2008). A brief initial warming up period followed by a main falling rate period has been similarly reported for the microwave drying of Gundelia tournefortii (Ervin, 2012) and green microalgae paste biomass (Agbede et al., 2020).

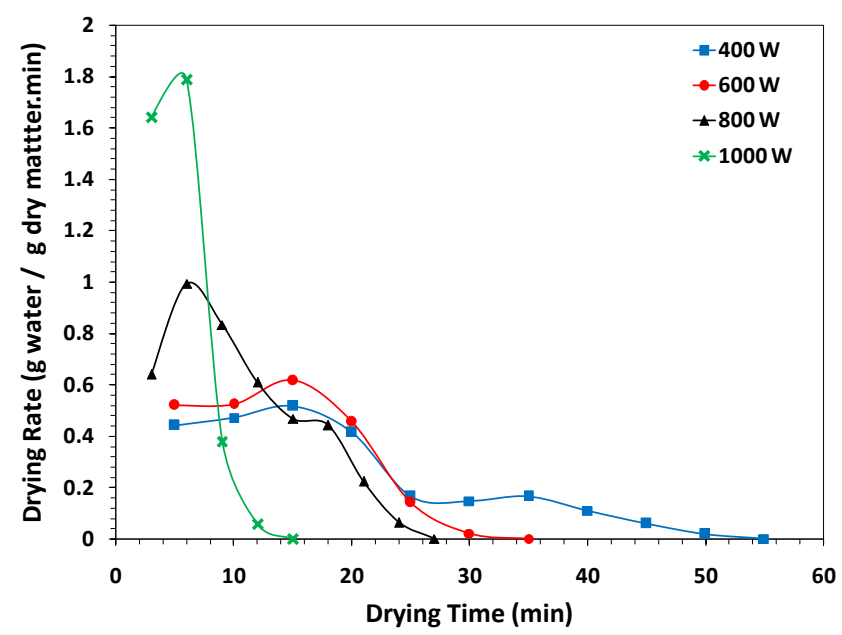

Figure 3: Plot of drying rate versus drying time for microwave drying of banana stalk slices

\section{Effective Moisture Diffusivities}

The measured effective moisture diffusivities for the microwave drying of banana stalk slices at 400, 600, 800 and $1000 \mathrm{~W}$ were $4.14 \times 10^{-9}, 7.56 \times 10^{-9}, 7.73 \times 10^{-9}$ and $2.00 \times 10^{-8} \mathrm{~m}^{2} \mathrm{~s}^{-1}$, respectively. They are within the range of $10^{-12}-10^{-6} \mathrm{~m}^{2} \mathrm{~s}^{-1}$ previously reported for agro-products (Erbay and Icier, 2010). The effective moisture diffusivity increased with increasing microwave power because the activity of moisture in the banana stalk increased due to the higher heating rate at higher microwave power resulting in larger moisture diffusivities. The effective moisture diffusivities for the microwave drying of banana stalk slices of $4.14 \times 10^{-9}-2.00 \times 10^{-8} \mathrm{~m}^{2} \mathrm{~s}^{-1}$ at 400 $-1000 \mathrm{~W}$ obtained in this study are larger than those of $2.168 \times 10^{-10}-7.899 \times 10^{-10}, 3.982 \times 10^{-11}$ $-2.073 \times 10^{-10}$ and $6.3 \times 10^{-11}-2.19 \times 10^{-10} \mathrm{~m}^{2} \mathrm{~s}^{-1}$ previously reported for the microwave drying of basil leaves (Demirhan and Özbek, 2009), mint leaves (Özbek and Dadali, 2007) and coriander leaves (Sarimeseli, 2011), respectively. However, they are lower than $8.315 \times 10^{-8}-2.363 \times 10^{-7}$ and $5.5 \times 10^{-8}-3.5 \times 10^{-7} \mathrm{~m}^{2} \mathrm{~s}^{-1}$ reported for the microwave drying of green pepper (Darvishi et al., 2014) and Gundelia tournefortii (Ervin, 2012), respectively.

\section{Activation Energy}

The effective moisture diffusivity was well described by the Arrhenius-type equation 10, the activation energy for microwave drying of the banana stalk slices was $122 \mathrm{~W} \mathrm{~g}^{-1}$. This energy is a measure of the energy required to initiate diffusion of moisture from the inner part of the stalk slice to its surface. It is far larger than those of 10.43, 12.28, 14.19, 21.40 and $39.32 \mathrm{~W} / \mathrm{g}$ reported for the microwave drying of basil leaves (Demirhan and Özbek, 2009), mint leaves (Özbek and Dadali, 2007), green pepper (Darvishi et al., 2014), microalgae paste (Agbede et al., 2020) and turmeric slices (Surendhar et al., 2019), respectively. 


\section{Microwave Drying Energy}

The total and specific energies required for microwave drying of banana stalk slices at $400-1000$ $\mathrm{W}$ are shown in Figure 4 and Figure 5, respectively. Both the total and specific energies required for microwave drying of the banana stalk slices did not change significantly at power levels lower than $1000 \mathrm{~W}$, but decreased significantly at $1000 \mathrm{~W}$ due to higher drying rate and shorter drying time achieved at this power level. The total and specific energies for the microwave drying of banana stalk slices were $0.25-0.37 \mathrm{kWh}$ and $34.8-51 \mathrm{kWh} / \mathrm{kg}$, respectively. The specific energies required for microwave drying of banana stalk slices at $400-1000 \mathrm{~W}$ are much higher than those of $2.72-$ $6.84 \mathrm{kWh} / \mathrm{kg}$ required for microwave drying of turmeric slices at $270-900 \mathrm{~W}$ (Surendhar et al., 2019).

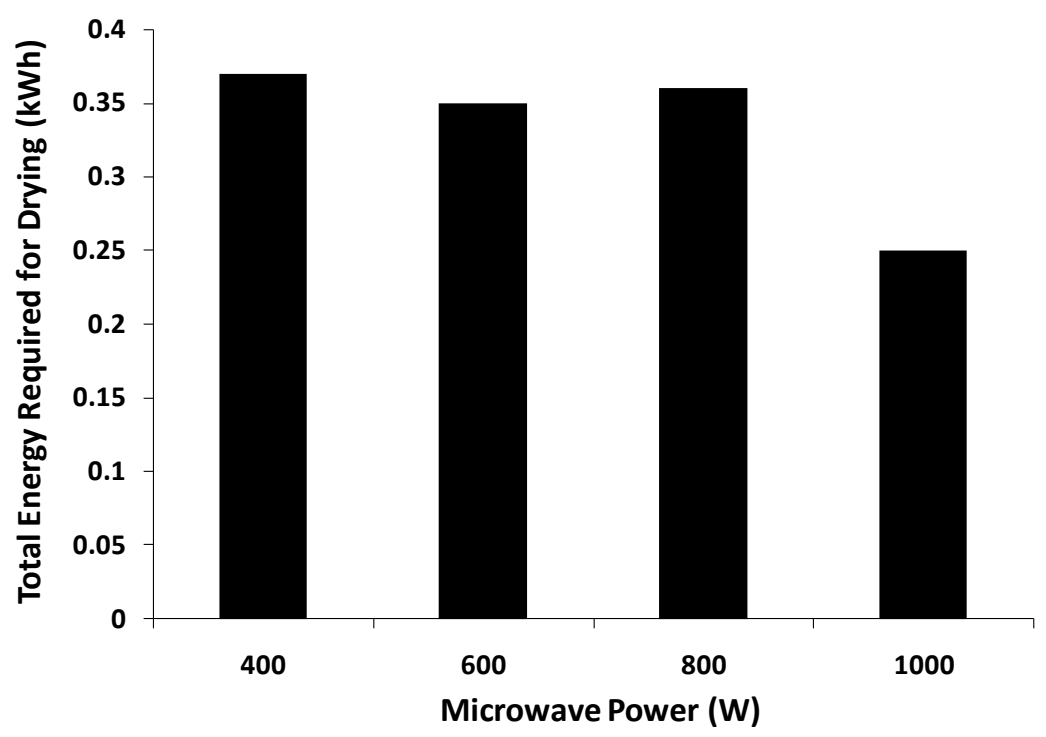

Figure 4: Total energy required for microwave drying of banana stalk slices at $400-1000 \mathrm{~W}$

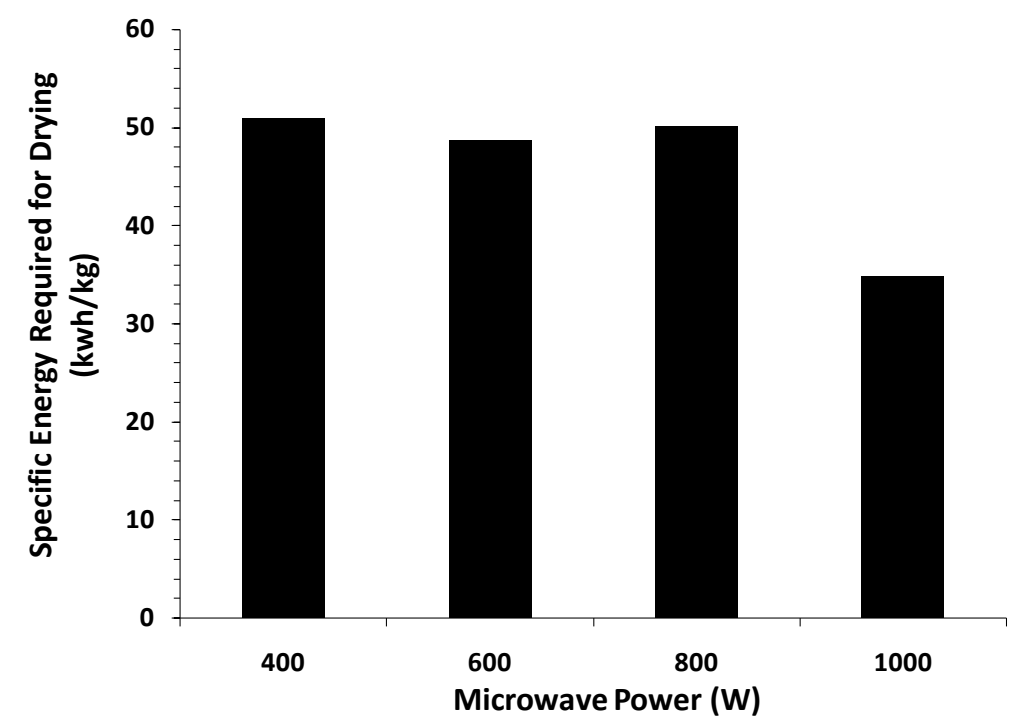

Figure 5: Specific energy required for microwave drying of banana stalk slices at $400-1000 \mathrm{~W}$ 
LAUTECH Journal of Civil and Environmental Studies

Volume 6, Issue 1; March 2021

\section{Microwave Drying Kinetics}

The constants and statistical parameters obtained when the thin layer drying models were fitted to the microwave drying data are presented in Tables 2 - 5. The Midilli-Kucuk, Page, modified page, Verma and Weibull models had the highest $R^{2}$ value of 0.998 compared to the other seven models, these five models also had the lowest SSE (0.0002), RMSE $(<0.0153)$ and $\chi^{2}(<0.0004)$ values at the microwave power $400 \mathrm{~W}$ compared to the other seven models as shown in Table 2. The MidilliKucuk and Weibull models had the highest $R^{2}$ value of 0.996 compared to the other ten models, both models also have the lowest value of SSE (0.0006), but the Weibull model had lower RMSE $(0.0248)$ and $\chi^{2}(0.0012)$ values at the microwave power $600 \mathrm{~W}$ as shown in Table 3.

Table 2: Constants and statistical parameters of the thin layer drying models for microwave drying of banana stalk at $400 \mathrm{~W}$

\begin{tabular}{llcccc}
\hline \multicolumn{1}{c}{ Model } & \multicolumn{1}{c}{ Model Constants } & $\mathrm{R}^{2}$ & $\mathrm{SSE}$ & $\mathrm{RMSE}$ & $\chi^{2}$ \\
\hline Midilli-Kucuk & $\mathrm{a}=1.001, \mathrm{~b}=0, \mathrm{k}=0.022, \mathrm{n}=1.337$ & 0.998 & 0.0002 & 0.0152 & 0.0003 \\
Page & $\mathrm{k}=0.02, \mathrm{n}=1.373$ & 0.998 & 0.0002 & 0.0141 & 0.0002 \\
Logarithmic & $\mathrm{a}=1.142, \mathrm{c}=-0.101, \mathrm{k}=0.051$ & 0.992 & 0.0008 & 0.0290 & 0.0011 \\
Two-term & $\mathrm{a}=0.533 \mathrm{~b}=0.533, \mathrm{k}_{0}=0.065, \mathrm{k}_{1}=0.065$ & 0.982 & 0.0020 & 0.0446 & 0.0030 \\
Wang and Singh & $\mathrm{a}=-0.043, \mathrm{~b}=0$ & 0.995 & 0.4387 & 0.6623 & 0.5264 \\
Approximation of diffusion & $\mathrm{a}=1, \mathrm{~b}=1, \mathrm{k}=0.061$ & 0.997 & 0.0025 & 0.0504 & 0.0033 \\
Modified Henderson and & $\mathrm{a}=0.356, \mathrm{~b}=0.356, \mathrm{c}=0.356, \mathrm{~g}=0.065$, & 0.982 & 0.0020 & 0.0446 & 0.0040 \\
Pabis & $\mathrm{h}=0.065, \mathrm{k}=0.065$ & 0.998 & 0.0002 & 0.0140 & 0.0002 \\
Modified Page & $\mathrm{k}=0.058, \mathrm{n}=1.373$ & 0.982 & 0.0020 & 0.0446 & 0.0024 \\
Henderson and Pabis & $\mathrm{a}=1.067, \mathrm{k}=0.065$ & 0.977 & 0.0025 & 0.0504 & 0.0030 \\
Two-term exponential & $\mathrm{a}=1, \mathrm{k}=0.061$ & 0.998 & 0.0002 & 0.0148 & 0.0003 \\
Verma & $\mathrm{a}=4.259, \mathrm{~g}=0.134, \mathrm{k}=0.106$ & 0.998 & 0.0002 & 0.0131 & 0.0003 \\
Weibull & $\mathrm{a}=-0.014, \mathrm{~b}=-1.016, \mathrm{k}=0.022, \mathrm{n}=1.33$ \\
\hline
\end{tabular}

Table 3: Constants and statistical parameters of the thin layer drying models for microwave drying of banana stalk at $600 \mathrm{~W}$

\begin{tabular}{llcccc}
\hline \multicolumn{1}{c}{ Model } & \multicolumn{1}{c}{ Model Constants } & $\mathrm{R}^{2}$ & SSE & RMSE & $\chi^{2}$ \\
\hline Midilli-Kucuk & $\mathrm{a}=0.983, \mathrm{~b}=-0.001, \mathrm{k}=0.011, \mathrm{n}=1.766$ & 0.996 & 0.0006 & 0.0253 & 0.0013 \\
Page & $\mathrm{k}=0.012, \mathrm{n}=1.757$ & 0.995 & 0.0007 & 0.0259 & 0.0009 \\
Logarithmic & $\mathrm{a}=1.259, \mathrm{c}=-0.214, \mathrm{k}=0.016$ & 0.977 & 0.2181 & 0.4671 & 0.3490 \\
Two-term & $\mathrm{a}=0.537, \mathrm{~b}=0.537, \mathrm{k}=0.092, \mathrm{k}_{1}=0.092$ & 0.951 & 0.0067 & 0.0816 & 0.0133 \\
Wang and Singh & $\mathrm{a}=-0.062, \mathrm{~b}=0.001$ & 0.987 & 0.0031 & 0.0553 & 0.0041 \\
Approximation of diffusion & $\mathrm{a}=1, \mathrm{~b}=1, \mathrm{k}=0.087$ & 0.944 & 0.0075 & 0.0866 & 0.0120 \\
Modified Henderson and & $\mathrm{a}=0.358, \mathrm{~b}=0.358, \mathrm{c}=0.358, \mathrm{~g}=0.092$, & 0.951 & 0.0067 & 0.0816 & 0.0266 \\
Pabis & $\mathrm{h}=0.092, \mathrm{k}=0.092$ & 0.995 & 0.0007 & 0.0258 & 0.0009 \\
Modified Page & $\mathrm{k}=0.08, \mathrm{n}=1.757$ & 0.944 & 0.0067 & 0.0816 & 0.0089 \\
Henderson and Pabis & $\mathrm{a}=1.073, \mathrm{k}=0.092$ & 0.944 & 0.0075 & 0.0866 & 0.0100 \\
Two-term exponential & $\mathrm{a}=1, \mathrm{k}=0.087$ & 0.989 & 0.0015 & 0.0382 & 0.0023 \\
Verma & $\mathrm{a}=9.395, \mathrm{~g}=0.201, \mathrm{k}=0.117$ & 0.996 & 0.0006 & 0.0248 & 0.0012 \\
Weibull & $\mathrm{a}=-0.02, \mathrm{~b}=-1.004, \mathrm{k}=0.011, \mathrm{n}=1.742$ & & & & \\
\hline
\end{tabular}


Also, for the microwave drying data obtained at $800 \mathrm{~W}$, the Midilli-Kucuk and Weibull models had the highest $R^{2}$ value of 0.999 compared to the other ten models, both models also have the lowest values of SSE (0.0001) and $\chi^{2}(0.0002)$, but the Weibull model had an RMSE value of 0.0108 which was lower than that of 0.0110 obtained for the Midilli-Kucuk model as shown in Table 4. The Midilli-Kucuk, Page, modified Henderson and Pabis, modified Page, Verma and Weibull models had the highest $R^{2}$ value of 1.000 compared to the other models for microwave drying of banana stalk slices at $1000 \mathrm{~W}$, these models also have lower SSE $(<0.0054), R M S E(<0.0732)$ and $\chi^{2}$ $(<0.0375)$ values. Notably, the Weibull model had SSE, RMSE and $\chi^{2}$ values of $0.0039,0.0628$ and 0.0092 , respectively, as shown in Table 5. Hence, the Weibull model was deemed to best fit the microwave drying data.

Table 4: Constants and statistical parameters of the thin layer drying models for microwave drying of banana stalk at $800 \mathrm{~W}$

\begin{tabular}{llcccc}
\hline \multicolumn{1}{c}{ Model } & \multicolumn{1}{c}{ Model Constants } & $\mathrm{R}^{2}$ & $\mathrm{SSE}$ & $\mathrm{RMSE}$ & $\chi^{2}$ \\
\hline Midilli-Kucuk & $\mathrm{a}=1, \mathrm{~b}=-0.001, \mathrm{k}=0.033, \mathrm{n}=1.47$ & 0.999 & 0.0001 & 0.0110 & 0.0002 \\
Page & $\mathrm{k}=0.029, \mathrm{n}=1.542$ & 0.998 & 0.0002 & 0.0153 & 0.0003 \\
Logarithmic & $\mathrm{a}=1.259, \mathrm{c}=-0.212, \mathrm{k}=0.076$ & 0.990 & 0.0012 & 0.0353 & 0.0018 \\
Two-term & $\mathrm{a}=0.542 \mathrm{~b}=0.542, \mathrm{k}_{0}=0.115, \mathrm{k}_{1}=0.115$ & 0.967 & 0.0040 & 0.0631 & 0.0066 \\
Wang and Singh & $\mathrm{a}=-0.077, \mathrm{~b}=0.001$ & 0.995 & 0.0272 & 0.1649 & 0.0340 \\
Approximation of diffusion & $\mathrm{a}=1, \mathrm{~b}=1, \mathrm{k}=0.107$ & 0.959 & 0.0050 & 0.0706 & 0.0071 \\
Modified Henderson and & $\mathrm{a}=0.361, \mathrm{~b}=0.361, \mathrm{c}=0.361, \mathrm{~g}=0.115$, & 0.967 & 0.0034 & 0.0631 & 0.0100 \\
Pabis & $\mathrm{h}=0.115, \mathrm{k}=0.115$ & 0.321 & 0.0830 & 0.2881 & 0.1037 \\
Modified Page & $\mathrm{k}=0.132, \mathrm{n}=3.81 \mathrm{x} 10^{-17}$ & 0.967 & 0.0040 & 0.0631 & 0.0050 \\
Henderson and Pabis & $\mathrm{a}=1.084, \mathrm{k}=0.115$ & 0.959 & 0.0050 & 0.0706 & 0.0062 \\
Two-term exponential & $\mathrm{a}=1, \mathrm{k}=0.107$ & 0.996 & 0.0005 & 0.0216 & 0.0007 \\
Verma et al & $\mathrm{a}=6.374, \mathrm{~g}=0.245, \mathrm{k}=0.205$ & 0.999 & 0.0001 & 0.0108 & 0.0002 \\
Weibull et al & $\mathrm{a}=-0.034, \mathrm{~b}=-1.034, \mathrm{k}=0.033, \mathrm{n}=1.451$ \\
\hline
\end{tabular}

A comparison of moisture ratios predicted by the Weibull model with experimental moisture ratios is shown in Figure 6. The predicted moisture ratios are in good agreement with the experimental moisture ratios $\left(\mathrm{R}^{2}\right.$ values of $\left.0.996-1.000\right)$, indicating that the Weibull model suitably described the microwave drying kinetics of banana stalk slices. 
LAUTECH Journal of Civil and Environmental Studies

Volume 6, Issue 1; March 2021

Table 5: Constants and statistical parameters of the thin layer drying models for microwave drying of banana stalk at $1000 \mathrm{~W}$

\begin{tabular}{llcccc}
\hline \multicolumn{1}{c}{ Model } & \multicolumn{1}{c}{ Model Constants } & $\mathrm{R}^{2}$ & $\mathrm{SSE}$ & $\mathrm{RMSE}$ & $\chi^{2}$ \\
\hline Midilli-Kucuk & $\mathrm{a}=1, \mathrm{~b}=0, \mathrm{k}=0.064, \mathrm{n}=1.971$ & 1.000 & 0.0042 & 0.0647 & 0.0098 \\
Page & $\mathrm{k}=0.064, \mathrm{n}=1.967$ & 1.000 & 0.0041 & 0.0639 & 0.0057 \\
Logarithmic & $\mathrm{a}=1.106, \mathrm{c}=-0.081, \mathrm{k}=0.229$ & 0.974 & 0.0047 & 0.0687 & 0.0083 \\
Two-term & $\mathrm{a}=0.516 \mathrm{~b}=0.516, \mathrm{k}_{0}=0.277, \mathrm{k}_{1}=0.277$ & 0.965 & 0.0053 & 0.0731 & 0.0125 \\
Wang and Singh & $\mathrm{a}=-0.18, \mathrm{~b}=0.008$ & 0.985 & 0.0211 & 0.1453 & 0.0296 \\
Approximation of diffusion & $\mathrm{a}=1, \mathrm{~b}=1, \mathrm{k}=0.271$ & 0.964 & 0.0055 & 0.0743 & 0.0097 \\
Modified Henderson and & $\mathrm{a}=0.344, \mathrm{~b}=0.344, \mathrm{c}=0.344, \mathrm{~g}=0.277$, & 1.000 & 0.0053 & 0.0731 & 0.0374 \\
Pabis & $\mathrm{h}=0.277, \mathrm{k}=0.277$ & 1.000 & 0.0041 & 0.0637 & 0.0057 \\
Modified Page & $\mathrm{k}=0.247, \mathrm{n}=1.967$ & 0.965 & 0.0053 & 0.0731 & 0.0075 \\
Henderson and Pabis & $\mathrm{a}=1.032, \mathrm{k}=0.277$ & 0.964 & 0.0055 & 0.0743 & 0.0077 \\
Two-term exponential & $\mathrm{a}=1, \mathrm{k}=0.271$ & 1.000 & 0.0039 & 0.0627 & 0.0069 \\
Verma & $\mathrm{a}=5.528, \mathrm{~g}=0.947, \mathrm{k}=0.628$ & 1.000 & 0.0039 & 0.0628 & 0.0092 \\
Weibull & $\mathrm{a}=-0.002, \mathrm{~b}=-0.998, \mathrm{k}=0.063, \mathrm{n}=1.976$ \\
\hline
\end{tabular}

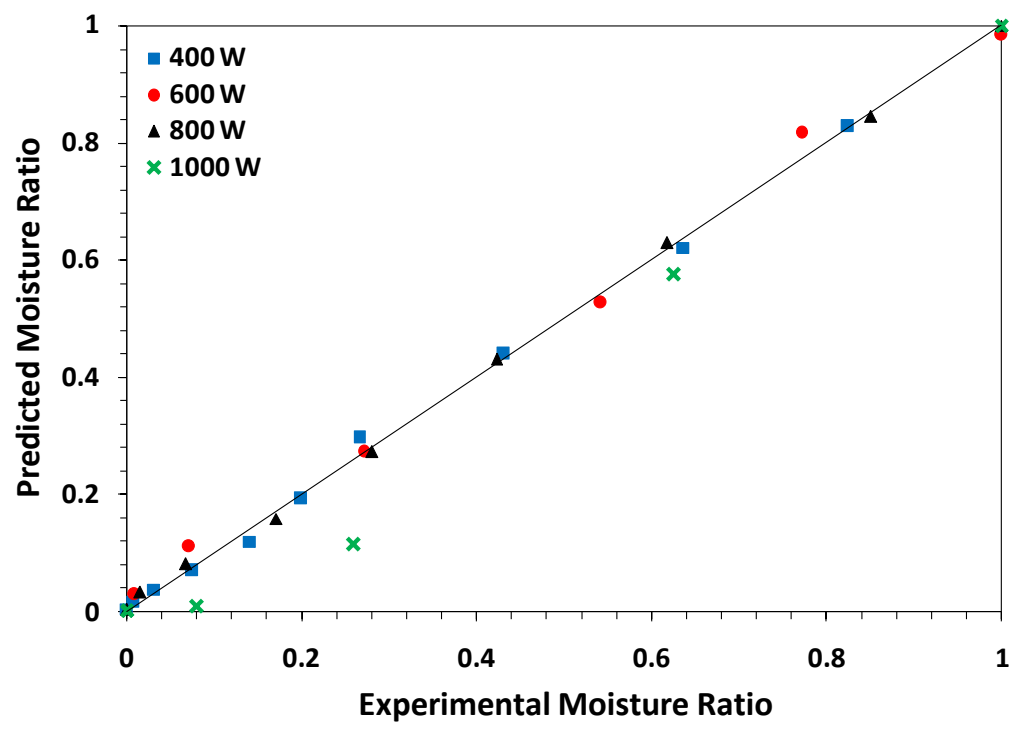

Figure 6: Comparison of Weibull model predicted moisture ratio and experimental moisture ratio for microwave drying of banana stalk slices

\section{Conclusion}

The microwave drying of banana stalk biomass was controlled by moisture migration within the biomass. The drying rate of the biomass can be appreciably enhanced by drying at higher microwave powers. An Arrhenius-type equation suitably described the microwave power dependence of the effective moisture diffusivity, with activation energy of $122 \mathrm{~W} \mathrm{~g}^{-1}$. The specific energy required for drying banana stalk slices can be significantly reduced by drying at microwave power levels higher than $800 \mathrm{~W}$. The Weibull thin layer drying mathematical model well described the microwave drying kinetics of banana stalk slices. 


\section{References}

Agbede, O.O., Oke, E.O., Akinfenwa, S.I., Wahab, K.T., Ogundipe, S., Aworanti, O.A., Arinkoola, A.O., Agarry, S.E., Ogunleye, O.O., Osuolale, F.N. and Babatunde, K.A. (2020). Thin layer drying of green microalgae (Chlorella sp.) paste biomass: Drying characteristics, energy requirement and mathematical modeling.Bioresource Technology Reports, 11: 100467. https://doi.org/10.1016/j.biteb.2020.100467

Ajila, C.M., Brar, S.K., Verma, M., Tyagi, R.D., Godbout, S. and Valéro, J.R. (2012). Bioprocessing of agro-byproducts to animal feed. Critical Reviews in Biotechnology, 32 (4): 382 400. https://doi.org/10.3109/07388551.2012.659172

Akpinar, E. K. and Bicer, Y. (2008). Mathematical modelling of thin layer drying process of long green pepper in solar dryer and under open sun. Energy Conversion and Management, 49 (6): 1367-1375. https://doi.org/10.1016/j.enconman.2008.01.004

Alibas Ozkan, I., Akbudak, B. and Akbudak, N. (2007). Microwave drying characteristics of spinach. Journal of Food Engineering, 78 (2): 577-583.

https://doi.org/10.1016/j.jfoodeng.2005.10.026

Barskov, S., Zappi, M., Buchireddy, P., Dufreche, S., Guillory, J., Gang, D., Hernandez, R., Bajpai, R., Baudier, J., Cooper, R. and Sharp, R. (2019). Torrefaction of biomass: A review of production methods for biocoal from cultured and waste lignocellulosic feedstocks. Renewable Energy, 142: 624-642. https://doi.org/10.1016/j.renene.2019.04.068

Chandra, P. K. and Singh, R. P. (1995). Applied Numerical Methods for Food and Agricultural Engineers, CRC Press, Boca Raton, FL.

Chandrasekaran, S., Ramanathan, S. and Basak, T. (2013). Microwave food processing - A review. Food Research International, 52 (1): 243-261.

https://doi.org/10.1016/j.foodres.2013.02.033

Crank, J. (1975). The Mathematics of Diffusion, second ed. Oxford University Press, London, UK.

Darvishi, H., Asl, A. R., Asghari, A., Azadbakht, M., Najafi, G. and Khodaei, J. (2014). Study of the drying kinetics of pepper. Journal of the Saudi Society of Agricultural Sciences, 13 (2): 130 -138. https://doi.org/10.1016/j.jssas.2013.03.002

Demirbas, A. (2004). Effect of initial moisture content on the yields of oily products from pyrolysis of biomass. Journal of Analytical and Applied Pyrolysis, 71 (2): 803-815. https://doi.org/10.1016/j.jaap.2003.10.008

Demirhan, E. and Özbek, B. (2009). Microwave-Drying Characteristics of Basil. Journal of Food Processing and Preservation, 34 (3): 476-494. https://doi.org/10.1111/J.17454549.2008.00352.X

Deumaga, M.F.T., Emaga, T.H., Tchokouassom, R., Vanderghem, C. Aguedo, M., Gillet, S., Jacquet, N., Danthine, S., Magali, D. and Richel, A. (2015). Genotype contribution to the chemical composition of banana rachis and implications for thermo/biochemical conversion. Biomass Conversion and Biorefinery. 5: 409-416. https://doi.org/10.1007/s13399-015-0158-6.

Dhyani V. and Bhaskar T. A. (2017). Comprehensive review on the pyrolysis of lignocellulosic biomass, Renewal Energy, 129: 695-716. https://doi.org/10.1016/j.renene.2017.04.035.

Di Scala, K. and Crapiste, G. (2008). Drying kinetics and quality changes during drying of red pepper. LWT - Food Science and Technology, 41 (5): 789-795.

https://doi.org/10.1016/j.lwt.2007.06.007

Doymaz, I. (2008). Influence of blanching and slice thickness on drying characteristics of leek slices. Chemical Engineering and Processing: Process Intensification, 47 (1): 41-47. https://doi.org/10.1016/j.cep.2007.09.002 
LAUTECH Journal of Civil and Environmental Studies

Volume 6, Issue 1; March 2021

Erbay, Z. and Icier, F. (2010). A Review of Thin Layer Drying of Foods: Theory, Modeling, and

Experimental Results. Critical Reviews in Food Science and Nutrition,50 (5): 441-464.

https://doi.org/10.1080/10408390802437063

Evin, D. (2012). Thin layer drying kinetics of Gundelia tournefortii L. Food and Bioproducts Processing, 90 (2): 323-332. https://doi.org/10.1016/j.fbp.2011.07.002

FAO (2020a). Banana facts and figures - http://www.fao.org/economic/est/estcommodities/bananas/bananafacts/en/\#.Xt9hWtKnHMx (accessed $15^{\text {th }}$ September, 2020)

FAO (2020b). Prospects for global production and trade in bananas and tropical fruits $2019-2028$, Food and Agriculture Organization of the United Nations, http://www.fao.org/3/ca7568en/ca7568en.pdf (last accessed; $15^{\text {th }}$ September, 2020)

Fernandes, E.R.K., Marangoni, C., Souza, O. and Sellin, N. (2013). Thermochemical characterization of banana leaves as a potential energy source. Energy Conversion and Management, 75: 603-608.https://doi.org/10.1016/j.enconman.2013.08.008

Glenn, T.L. (1978). Dynamic analysis of grain drying system. Ph.D. Thesis, Ohio State University, Ann Arbor, MI (unpublished).

Granados, D.A., Velasquez, H.I. and Chejne, F. (2014). Energetic and exergetic evaluation of residual biomass in a torrefaction process. Energy, 74: 181-189.

https://doi.org/10.1016/j.energy.2014.05.046

Guerrero, A.B., Aguado, P.L., Sánchez, J. and Curt, M.D. (2016). GIS-Based Assessment of Banana Residual Biomass Potential for Ethanol Production and Power Generation: A Case Study. Waste and Biomass Valorization, 7: 405-415. https://doi.org/10.1007/s12649-0159455-3

Guerrero, A.B., Ballesteros, I. and Ballesteros. M. (2018). The potential of agricultural banana waste for bioethanol production. Fuel, 213: 176-185.https://doi.org/10.1016/j.fuel.2017.10.105

Gumisiriza, R., Hawumba, J.F., Okure, M. and Hensel, O. (2017). Biomass waste-to-energy valorization technologies: a review case for banana processing in Uganda. Biotechnology for Biofuels, 10, 11. https://doi.org/10.1186/s13068-016-0689-5

Hameed, B.H., Mahmoud, D.K. and Ahmad, A.L. (2008). Sorption equilibrium and kinetics of basic dye from aqueous solution using banana stalk waste. Journal of Hazardous Materials, 158 (23): 499-506. https://doi.org/10.1016/j.jhazmat.2008.01.098

Henderson, S.M. (1974). Progress in developing the thin layer drying equation. Transactions of the ASAE. 17: 1167-1172.

Henderson, S.M. and Pabis, S. (1961). Grain drying theory I: Temperature effect on drying coefficient. Journal of Agricultural Engineering Research, 6: 169-174.

Hughes, W. E. M. and Larson, E. D. (1998). Effect of Fuel Moisture Content on Biomass-IGCC Performance. Journal of Engineering for Gas Turbines and Power, 120 (3): 455-459.

https://doi.org/10.1115/1.2818166

Islam, A., Akber, A., Limon, S.H., Akbor, A. and Islam, A. (2019). Characterization of solid biofuel produced from banana stalk via hydrothermal carbonization. Biomass Conversion and Biorefinery. 9: 651-658.https://doi.org/10.1007/s13399-019-00405-5

Karathanos, V.T. (1999). Determination of water content of dried fruits by drying kinetics. Journal of Food Engineering, 39 (4): 337-344. https://doi.org/10.1016/S0260-8774(98)00132-0

Kaseem, A.S. (1998). Comparative studies on thin layer drying models for wheat. In 13th International Congress on Agricultural Engineering, $2^{\text {nd }} 6^{\text {th }}$ February, Morocco.

Kucuk, H., Midilli, A. Kilic, A and Dincer, I. (2014). A Review on Thin-Layer Drying-Curve Equations. Drying Technology, 32 (7): 757-773.

https://doi.org/10.1080/07373937.2013.873047

Leao, A.L., Souza, S.F., Cherian, B.M., Frollini, E., Thomas, S. Pothan, L.A. and Kottaisamy, M. (2010). Agro-Based Biocomposites for Industrial Applications. Molecular Crystals and Liquid Crystals, 522 (1): 18[318]-27[327]. https://doi.org/10.1080/15421401003719852. 
Liao, F., Liu, Y., Li, Q., Li, Y-R., Yang, L-T., Anas, M. and Huagn, D-L. (2018). Characteristics and inorganic $\mathrm{N}$ holding ability of biochar derived from the pyrolysis of agricultural and forestal residues in the southern China. Journal of Analytical and Applied Pyrolysis, 134: 544-551. https://doi.org/10.1016/j.jaap.2018.08.001

McKendry P. (2002). Energy production from biomass (part 3): gasification technologies. Bioresource Technology, 83 (1): 55-63. https://doi.org/10.1016/S0960-8524(01)00120-1

Midilli, A., Kucuk, H. and Yapar, Z. (2002). A new model for single-layer drying. Drying Technology, 20 (7): 1503-1513. https://doi.org/10.1081/DRT-120005864

Mohapatra, D., Mishra, S. and Sutar, N. (2010). Banana and its by-product utilisation: an overview. Journal of Scientific and Industrial Research. 69: 323-329.

Mohapatra, D., Mishra, S., Singh, C.B. and Jayas, D.S. (2011). Post-harvest Processing of Banana: Opportunities and Challenges. Food and Bioprocess Technology, 4: 327-339. https://doi.org/10.1007/s11947-010-0377-6

Mujumdar, A.S. and Law, C.L. (2010). Drying technology: trends and applications in post-harvest processing. Food and Bioprocess Technology, 3: 843-852.

https://doi.org/10.1007/s11947-010-0353-1

Ogunleye, O.O., Ajala, M.A. and Agarry, S.E. (2014). Evaluation of biosorptive capacity of banana (Musa paradisiaca) stalk for lead (II) removal from aqueous solution. Journal of Environmental Protection, 5: 1451-1465.

Ogunleye O.O., Ajala M.A., Agarry S.E. and Agbede O.O. (2015a). Experimental Optimization of Lead (II) Bioadsorption from Aqueous Solution onto Banana Stalk using Central Composite Design. Chemistry and Materials Research, 7 (11): 35-49.

Ogunleye, O.O., Adio, O., Salawudeen, T.O. and Agbede, O.O. (2015b). Optimal Adsorption Parameters of Banana (Musa Padadesica) Stalk based Activated Carbon for Removal of Lead (II) from Aqueous Solution. InternationalJournal of Scientific and Engineering Research, 6 (8): 499- 507.

Ogunsile, B.O. and Oladeji, T.G. (2016). Utilization of banana stalk fiber as reinforcement in low density polyethylene composite. revista Matéria, 21 (4): 953-963. http://dx.doi.org/10.1590/s1517-707620160004.0088

Olanipekun, B.F., Tunde-Akintunde, T.Y., Oyelade, O.J., Adebisi, M.G. and Adenayan, T.A. (2015) Mathematical Modeling of Thin-Layer Pineapple Drying. Journal of Food Processing and Preservation, 39 (6): 1431-1441. https://doi.org/10.1111/jfpp.12362

Özbek, B. and Dadali, G. (2007). Thin-layer drying characteristics and modelling of mint leaves undergoing microwave treatment. Journal of Food Engineering, 83 (4): 541549. https://doi.org/10.1016/j.jfoodeng.2007.04.004

Padam, B.S., Tin, H.S., Chye, F.Y. and Abdullah, M.I. (2014). Banana by-products: an underutilized renewable food biomass with great potential. Journal of Food Science and Technology, 51: 3527-3545. https://doi.org/10.1007/s13197-012-0861-2

Page, G.E. (1949). Factors influencing the maximum rate of air drying shelled corn in thin-layers. M.S.Thesis, Purdue University, West Lafayette, Indiana.

Perea-Flores, M.J., Garibay-Febles, V., Chanona-Pérez, J.J., Calderón-Domínguez, G., MéndezMéndez, J.V. and Gutiérrez-López, G.F. (2012). Mathematical modelling of castor oil seeds (Ricinus communis) drying kinetics in fluidized bed at high temperatures. Industrial Crops and Products, 38: 64-71. https://doi.org/10.1016/j.indcrop.2012.01.008

Poyyamozhi, V.S. and Kadirvel, R. (1986). The value of banana stalk as a feed for goats. Animal Feed Science and Technology, 15: 95 - 100. https://doi.org/10.1016/0377-8401(86)90016-7

Rattanadecho, P. and Makul, N. (2015). Microwave-Assisted Drying: A Review of the State-of-theArt. Drying Technology, 34 (1): 1-38.https://doi.org/10.1080/07373937.2014.957764 
LAUTECH Journal of Civil and Environmental Studies

Volume 6, Issue 1; March 2021

Ruiz Celma, A., Rojas, S. and Lopez-Rodriguez, F. (2008). Mathematical modelling of thin layer infrared drying of wet olive husk. Chemical Engineering Processing: Process Intensification, 47 (9-10): 1810-1818. https://doi.org/10.1016/j.cep.2007.10.003

Santa-Maria, M., Ruiz-Colorado, A., Cruz, G. and Jeoh, T. (2013). Assessing the feasibility of biofuel production from lignocellulosic banana waste in rural agricultural communities in Peru and Colombia. Bioenergy Research, 6: 1000-1011. https://doi.org/10.1007/s12155-013-9333$\underline{4}$

Sarimeseli, A. (2011). Microwave drying characteristics of coriander (Coriandrum sativum L.) leaves. Energy Conversion and Management, 52 (2):1449-1453.

Sharaf-Eldeen, Y. I., Blaisdell, J.L. and Hamdy, M.Y. (1980). A model for ear corn drying. Transaction of the ASAE, 23: 1261-1271.

Shibi, I.G., Thayyath, S. and Anirudhan, T.S. (2006). Polymer-grafted banana (Musa paradisiaca) stalk as an adsorbent for the removal of lead (II) and cadmium (II) ions from aqueous solutions: kinetic and equilibrium studies. Journal of Chemical Technology and Biotechnology, 81: 433444. https://doi.org/10.1002/jctb.1423

Simmonds, N.W. (1962). The Evolution of the Bananas. Longmans, London.

Surendhar, A., Sivasubramanian, V., Vidhyeswari, D. and Deepanraj, B. (2019) Energy and exergy analysis, drying kinetics, modeling and quality parameters of microwave-dried turmeric slices. Journal of Thermal Analysis and Calorimetry, 136: 185-197. https://doi.org/10.1007/s10973-018-7791-9

Vega-Galvez, A., Miranda, M., Diaz, L.P., Lopez, L., Rodriguez, K. and Di Scala, K. (2010). Effective moisture diffusivity determination and mathematical modelling of the drying curves of the olive-waste cake. Bioresource Technology, 101 (19): 7265-7270. https://doi.org/10.1016/j.biortech.2010.04.040

Verma, L.R., Bucklin, R.A, Ednan, J.B. and Wratten, F.T. (1985). Effects of drying air parameters on rice drying models. Transaction of the ASAE, 28 (1): 296-301.

https://doi.org/10.13031/2013.32245

Viswanathan, K., Kadirvel, R. and Chandrasekaran, D. (1989). Nutritive Value of Banana Stalk (Musa cavendishi) as a Feed for Sheep. Animal Feed Science and Technology, 22: 327 - 332. https://doi.org/10.1016/0377-8401(89)90076-X

Wang, C.Y. and Singh, R.P. (1978). A single layer drying equation for rough rice. ASAE Paper No. 3001.

Weibull, W. (1951). A statistical distribution of wide applicability. ASME Journal of Applied Mechanics, 18: 293-297.

White, G.M., Bridges, T.C., Loewer, O.J. and Ross, I.J. (1978). Seed coat damage in thin layer drying of soybeans as affected by drying conditions. ASAE paper no. 3052

Wray, D. and Ramaswamy, H. S. (2015). Novel Concepts in Microwave Drying of Foods. Drying Technology, 33 (7): 769-783. https://doi.org/10.1080/07373937.2014.985793

Zuluaga, R., Putaux, J-L., Restrepo, A., Mondragon, I. and Gañán, P. (2007). Cellulose microfibrils from banana farming residues: isolation and characterization. Cellulose, 14: 585-592. https://doi.org/10.1016/j.carbpol.2008.09.024

Zuluaga, R., Putaux, J-L., Cruz, J., Vélez, J., Mondragon, I. and Gañán, P. (2009). Cellulose microfibrils from banana rachis: Effect of alkaline treatments on structural and morphological features. Carbohydrate Polymers, 76: 51-59.

https://doi.org/10.1016/j.carbpol.2008.09.024 